\title{
Didactics of the use of ICT and traditional teaching aids in municipal higher education institutions.
}

\author{
Ideleichy Lombillo Rivero ${ }^{1,}$, Alexander López Padrón², Ernesto Zumeta Izaguirre ${ }^{3}$ \\ ${ }^{1}$ Centro de Estudios de la Educación Superior Agropecuaria (CEESA), Universidad Agraria de la Habana, \\ Cuba \{leixhy@isch.edu.cu\} \\ ${ }^{2}$ Centro de Estudios de la Educación Superior Agropecuaria (CEESA), Universidad Agraria de la Habana, \\ Cuba \{alejo@isch.edu.cu\} \\ ${ }^{3}$ Centro de Estudios de la Educación Superior Agropecuaria (CEESA), Universidad Agraria de la Habana, \\ Cuba
}

Received on 28 January 2012; revised on 20 Febraury 2012; accepted on 8 March 2012; published on15 July 2012

DOI: $10.7821 /$ naer.1.1.33-40

\begin{abstract}
Issues related to the use of teaching aids in Higher Education are currently going through constant revision and rethinking due to the rapid advancement of science and technology. Their uses have significantly changed after the introduction of Information and Communication Technologies (ICTs) within the educational field. One of the main tasks to be performed by didactics in Higher Education teaching today is precisely to deepen into rational and effective class-teaching means, understood in a broad sense: from traditional teaching aids to ICTs. This reality has materialized in the current blended learning model which characterizes the New Cuban University. Therefore, it was considered appropriate to characterize the present-day teaching practice, based on the use of teaching aids in Cuba's university classrooms, as part of the second stage within the research project "Improvement of the universalization process in Municipal Higher Education Institutions in the Havana province. Generalization of results and development of contextualized innovative experiences." The study was carried out at eleven 'Physical Culture' Municipal Higher Education Institutions (MHEls) in two academic periods (20072009 and 2009-2011). A descriptive methodology consisting of observation, surveys and the "Osgood Semantic Differential" scale as main methods and techniques was applied. The results obtained showed that teachers make an occasional, nonsystematic and reluctant use of teaching aids during the teachinglearning process, especially when it comes to ICT-based teaching aids.
\end{abstract}

KEYWORDS: HIGHER EDUCATION, DIDACTICS IN HIGHER EDUCATION, BLENDED LEARNING, TEACHING AIDS, INFORMATION AND COMMUNICATION TECHNOLOGIES (ICT)

\section{STATING THE PROBLEM}

One of the great challenges of the current Cuban educational model is to improve the curriculum in order to contribute to the training of professionals with a wide profile, which should be able to solve general and frequent professional problems that may appear in their working environment, thus favoring the socio-economic development of the country.

From this perspective, Cubero, González, Tristá, y Hernández (1985) point out that the improvement of higher education would not be possible if — apart from other aspects - no space is dedicated to study in depth the issue related to the teaching aids used in the teaching-learning process.

Nowadays, given the advancement of science and technology, the development of Information and Communication Technologies (ICT) and its impact on different processes taking place in modern society, the problems associated with the use of teaching aids have been the object of revision and reformulation. Thus, these teaching aids have been significantly modified with the introduction of the ICT in the educational field.

Therefore, it is a necessity to establish new ways to proceed with the teaching aids from a theory of their utilization taking into account the didactic principles of how to use them from a behaviorist and methodological perspective, leading to a preexisting logical articulation between the attitudes of the teachers and the use of teaching aids and their scientific, pedagogical and methodological preparation within the present context.

This involves updating the teaching strategies and procedures for teachers to adapt to the new challenges of the Knowledge and Information Society, and conceiving the use of teaching aids from a perspective of high rationality, using the basic resources required (Ministry of Higher Education, 2004).

Designing and implementing this aim - in the scenario where the teaching - learning process at the Municipal Higher Education Institutions (MHEIs) of Physical Culture takes place - means taking into account, among other aspects, the characteristics of the teaching staff in these centres. In most cases, these staff members have no teacher training and poor professional experience, mostly gained in in-class teaching.

From this situation - full of needs and barriers - concerning the use of teaching aids arises the main problem to be solved in this study, in which the authors intend to characterize the current practice of using teaching aids in a blended learning process in Municipal Higher Education Institutions (MHEIs) of Physical Culture in Havana province. 


\section{HISTORICAL AND THEORICAL BACKGROUND}

\subsection{General theorical aspects concerning the use of teaching aids in the teaching-learning process.}

The role of teaching aids as a part of the teaching-learning process (TLP) allows for reflection on the usefulness they may have in this process, which does not depend on the aids itself, but on the relationships established with the other systematic components that teachers provide with the implementation of appropriate strategies. They will define their role in the TLP basing on these relationships, for it is obvious that teaching aids do not work in a vacuum, but as part of a systematic, essentially interactive, communicative process, including a exchange of knowledge and experiences, prompting a mutual influence in interpersonal relationships (Rico, López, Chávez, Ruiz, \& Valera, 2002; Fernández, 2009).

According to Salinas (2002), the above-said study should include the analysis of problems associated with the availability of material aids, its economic and technological feasibility, but specially, the analysis of its teaching feasibility. This kind of study would be possible if teaching aids research is relocated within the field of didactics and the necessary systematic conception concerning their design, production, use and relation to other components of the teaching - learning process is assumed; thus, supporting their use in each of the organizational forms, with full knowledge of their possibilities and restrictions, according to the new realities and social and scientific demands, which will allow them to function and respond appropriately to the demands of today's society.

Horrutinier (2006) refers to this issue stating that, nowadays, it is a higth priority to increase the command of media and primarily of ICT in education to achieve a proper integration of teaching aids in the TLP. For this reason, the term integration from this perspective describes the condition of a system in which their component parts interact reciprocally.

The fact that the integration of this component in the teachinglearning process has been merely justified with the pretext of adding new teaching tools to the process is not an isolated case or a trend strange to the university teaching context. In fact, it has been a recurrent topic in the university policies in recent years, raising many challenges and questions about why, what and how to use teaching aids in the process in an integrated way.

Castañeda and Fernández de Alaiza (2002), Horrutinier (2006), López (2007), García Valcárcel and González (2011) and Lombillo (2011), advocate an idea, which is vital to understand, in every sense, the scope of this new quality; they state that the point is not simply to incorporate ICT as a teaching aid in the subjects and use them as mere instruments, but to use them in an innovative, thoughtful, integrated, progressive and didactic way. In essence, to transform the way to teach subjects with the use of teaching aids on the basis of the current principles of Cuban Higher Education, reinforcing the role of teachers in the process of education.

"And the transformation to be attained is, above all, a pedagogical transformation." "Because of the nature and complexity of these changes, this is one of the main challenges of the process of education, which will only depend on the performance of those involved, especially of teachers (Horrutinier, 2006, p.p. 116 and 118).

For all these reasons, the assimilation of ICT in the contemporary university should be considered by teachers "from two perspectives: as a teaching aid that contributes to improve the content of the teaching system of the subjects, and as a necessity caused by the transformation of professional practice "(López, 2005, p.5).

In this paper, the use of teaching aids is described in terms of activity carried on by the teachers in order to improve their teaching practice, during which they influence the students, so that they could study independently by using the means needed to acquire knowledge, regardless their location, their technological and physical resources or the physical presence or absence of the teacher.

From this perspective, it is understood that the use of teaching aids is a complex activity, and closely linked to aspects of psychology, pedagogy and philosophy, among others.

As a matter of fact, from the analysis of different studies on this topic we draw the conclusion that the great influence of teaching aids in schools has not been duly reflected in the curriculum (Pere, Devís, \& Peiró, 2008).

A teaching model and a way of determining the curriculum are directly defined by the use made of those teaching aids which are intended to promote learning (Area, 1999; Pere et al., 2008).

As rightly stated Escudero (1992) cited by Castaño (1994, p.1),

(...) the curricular integration of new media in education at different levels and stages is a major undertaking in which very heterogeneous decisions regarding structures, funding and technology are to be converged. Many of them related to general educational policy, concerning the provision of facilities and infrastructure and, of course, the adequate training of the faculty members.

It is also possible to analyze the interactive aspect of communication in the role that teaching aids play in TLP. In this communication process, teaching aids always use a language related to forms of human communication, based on a set of words, images, sounds and symbols that allow coding and are expressed in the different communication systems used: written, visual, oral and audiovisual (Bravo, 2004).

It is important to point out that this new mediation tool (ICT) enables bidirectional and even multidirectional communication that allows each person to fulfill both roles as sender/ receiver (López, 2005), making it a powerful medium of instruction.

Besides the possibilities of representing communication systems, different teaching aids have, in turn, another set of characteristics that make them interesting from the communication point of view: iconicity, synchrony and / or asynchrony.

One of the main contributions of the ICT-based teaching aids to the educational field - as expressed by Álvarez and Fuentes (2005) - is that they open a range of possibilities in training modalities that can be placed both in the field of distance education, as in the face-to-face instruction modalities.

The Ministry of Higher Education states that (2006, p. 4):

(...) a combination of aids to facilitate synchronous and asynchronous communication is convenient. The first would help to facilitate communication, to simulate and reconstruct face-to-face situations in in-class training sessions, while the second would give the possibility to acquire information from anywhere and 
anytime, enabling students to work at their own pace and take the time to read, reflect, write and revise, before sharing issues with others.

From the above mentioned it is possible to elucidate that the "role" of the teacher - as expressed by Marqués (2004), López (2007) and Castañeda, Ruiz and López (2010) — should not be reduced to the function of transmitting information to the students. In fact the teacher should become a mediator between culture and students, a knowledge manager that guides learning at group and individual level, as well as the students' access to information and communication channels supported by the media, guiding the selection and structuring of the available information. He should also make a formative evaluation, advise, manage group dynamics and motivate by creating a climate of trust and dialogue.

Many researchers devoted to the study of teaching aids have focused their analysis on teacher attitudes towards the material aids, how they use them - particularly the computer - and which role these aids play in the center (Castaño, 1994; Área, 1991; Salinas, 2002; Guzmán \& Aguaded, 2011; Lombillo, 2011). In all cases they found that teachers' training and experience on the use of teaching aids plays a main role.

As the result of the diagnostic carried out by Lombillo (2008) clearly shows, there is - despite the undeniable importance of the teaching aids, which most of the documents, researchers, and authors insist on highlighting - still some resistance from teachers regarding the use of teaching aids in the ongoing process of universalization, a reality that becomes more complex when it comes to the use of traditional teaching aids combined with ICT.

The new educational model - focused on student-centered learning - demands of a more trained university staff, from the psychodidactic point of view, to assume the teaching task. Evidently, this aim requires a precision in each of the nonpersonal aspects of TLP (objectives, contents, methods, evaluation, teaching aids) and a higher, innovative and creative use of the benefits and options provided by ICT training system that ensures an appropriate didactic system with the new requirements, education principles, consistent with the formative dimension to be achieved with regard to the university student.

"The greatest danger for education today is that we intend to do the same we did yesterday, with today's tools" (Castañeda \& Fernández de Alaiza, 2002), "without having the resources available at that historical time, wasting the possibilities offered by new tools today "(López, 2009). Thus, it is required to conduct an integrated use of teaching aids that contribute to the development of a process of gradual assimilation of ICT to transform TLP - as an opportunity for change - to a model focused on learning, students' personality development and dialogue between teachers and students.

\section{DESIGN AND METHODOLOGY}

The proposed objective was conceived -in the first stage (2007-2009) - as part of the tasks developed within the $\mathrm{R}+\mathrm{D}+\mathrm{i}$ research project "The universalized university in the SUM: Conception and innovative experience in the province of Havana" (Valera, 2008) and was completed in the second stage (2009-2011), supported by the research project REEDES of the Ministry of Higher Education (MHE) "Improvement of the universalization process in Municipal Higher Education
Institutions in Havana province. Generalization of results and development of contextualized innovative experiences".

The present study was carried out in this second stage and was developed in eleven Municipal Higher Education Institutions (MHEIs) of Physical Culture of the selected county during two academic courses (2009-2011), applying the descriptive methodology, using the observation, the survey and the "Osgood Semantic Differential" scale as main methods and techniques that facilitated the identification of the characteristics in which professors base their current educational practice with the use of teaching aids.

We verified the obtained information by analysing the results of the diagnostics offered by authors studying the same phenomena (López, 2005; Torres, 2008; Lombillo, 2006, 2008 $\& 2011$ ), which allowed us to "raise the objectiveness of the data analysis and to gain greater credibility with regard to the facts" (Ruiz, 1999, p. 94).

The procedure for selecting the sample to determine its distribution with respect to the population was not probabilistic, but intentional, which allowed a direct and explicit selection of subjects who were considered more accessible and likely to provide much information. It consisted of 98 teachers from 11 of the 19 Municipal Higher Education Institutions (MHEIs) of Physical Culture.

Class Observations: The used observation guide was validated by Gonzalez (1995) in the study of the educational process in the classroom. It allowed to evaluate the use of teaching aids in the TLP, through perception and systematic control and planned observation of 24 classes of courses belonging to the discipline of Biological Sciences in the major on Physical Culture: [Education, Morphology and Data Analysis (1st year ); Physiology and Psychology (2nd year) Biological Foundations of Physical Exercise (3rd year)].

Survey: It allowed a deeper view into issues concerning the use of teaching aids in the TLP, based on the use of data collection (questionnaires) and analysis techniques. The instrument was validated by Lombillo (2008) in the study on the use of teaching aids and ICT in Cuban universities.

Osgood Semantic Differential Scale: constituted a prior and / or intermediate detailed analysis of the traditional teaching aids (TTA) and ICT integration process, based on the practices of TLP in Municipal Higher Education Institutions (MIHE) in the major on Physical Culture, where the study was carried out. It was used for measuring the affective component (acceptancerejection) among the surveyed teachers towards the attitude object: Use of teaching aids in the TLP. The selected scale: Osgood semantic differential scale measures the situation of the concept of the attitude object within a semantic space of evaluative dimensions. For the application of this instrument, the following procedures —outlined by Lombillo (2008) — were taken into account:

(1) The selection of scales or relevant adjective pairs related to the attitude object to be evaluated.

(2) Elaborating the questionnaire.

(3) Randomization of the scales and calculation of the values given by individuals.

(4) Interpretation and discussion of results. 
Attitude objects subjected to evaluation were:

a) Use of teaching aids in the teaching-learning process.

b) Integration of ICT as teaching aids in the teachinglearning process.

The pairs of adjectives are represented by the following numeric system in the scale

$$
\begin{array}{ccccccccc}
\text { Adjectives } & - & \overline{1} & \overline{1} & \overline{0} & \overline{-1} & \overline{-2} & \overline{-3} & \text { Adjectives } \\
\text { Pleasant } & +3 & +2 & +1 & 0 & \text { Unpleasant }
\end{array}
$$

Each meaning is shown in the following table (Table 1):

Table 1. Meaning of the numeric system to interpret the scale

\begin{tabular}{cc}
\hline Sistema numérico & Significado \\
\hline+3 & Muy agradable \\
+2 & Bastante agradable \\
+1 & Algo agradable \\
0 & Ni agradable ni desagradable \\
-1 & Algo desagradable \\
-2 & Bastante desagradable \\
-3 & Muy desagradable \\
\hline
\end{tabular}

\section{RESULTS ANALYSIS AND DISCUSSION}

After the use of different methods and research techniques, the reflection on them and the empirical research analysis, the analysis of the current state of the problem was performed in order to determine the main regularities that characterize the use of teaching aids in the chosen Municipal Higher Education Institutions (MHEIs).

\subsection{Result analysis of the survey applied to teachers and class observations in the MHEIs.}

The implemented survey allowed the characterization of the use of ICT and its organization and planning by teachers. From the obtained data, it could be inferred that planning is irregular; and no organizational strategy regarding the use of teaching aids could be observed. Only a few Municipal Higher Education Institutions (MHEIs) try to organize the use of ICT by establishing strategic alliances with several educational institutions, for instance the Youngsters' Computer Clubs in the different communities; but - as reported by Cabero, Llorente, and Marín (2010) - they are not systematically established in relation to the objectives.

The above mentioned questionnaire inquires specifically what teaching aids are used by teachers during lessons. In these responses, it is clear that higher percentages - in relation to the frequency of use - are reported concerning the use of traditional tools (basically: oral communication, 97,9\%, and use of the blackboard ,89.7\%), while those using ICT tools (including chat ,5,1\%; electronic mails, $18,3 \%$, multimedia and educational software, $9,1 \%$ ) represent a lower percentage. The results agree with those obtained by Lombillo (2008), García-Valcárcel and Tejedor (2010), even in those works including innovative experiences based on the use of ICT. These results confirm the following:

- $\quad$ Teachers of the Municipal Higher Education Institutions (MHEIs) are not properly trained to meet the challenge imposed by the systematic assimilation of ICT in the educational process in coexistence with traditional teaching aids.
This conclusion agrees with the results achieved in other researches on the use of ICT in higher education, establising that teacher training in ICT "remains poor, not so much regarding the technical management, but the didactic and educational use"(Cabero et al., 2010).

The systematic relation between ICT and the existing traditional teaching aids remains unidentified.

With regard to this particular issue, the Director of Professional Training of the Ministry of Higher Education (MES) - in his book The Cuban university education modelstated that such a system is only complete if it succeeds to combine the materials used to foster a better communication in the face-to-face meetings (textbooks, study guides, etc.) with the material based on Educational Technologies conceived to support students' self-preparation; which is an essential feature of a blended learning approach "(Hurruitiner, 2006).

- The occasional use of teaching aids in teaching practice in Municipal Higher Education Institutions (MHEIs) is made ignoring the dynamics between tradition and technology that should be considered in a self-developing learning. This result coincides with that obtained by García-Valcárcel and Tejedor (2010), in which traditional teaching aids are acknowledged to have a greater potential to facilitate learning and a greater influence on grades.

- Consequently, a large number of teachers agree that the causes that determine the use of ICT in TLP is closely related to the inadequate availability and access to ICT in Municipal Higher Education Institutions (MHEIs) (82.6\%), to the inadequate skills for management $(75.5 \%)$, and to the absence of a design and a strategy due to the teachers' low level of technological literacy. These difficulties have already been identified in the investigations by Roig (2010), Cabero et al. (2010), Nápoles (2011) and Guzmán and Aguaded (2011).

- Within the identified challenges, the lack of a conceptual and methodological framework that supports the integrated use of these teaching elements in the TLP according to the new requirements and the existing pedagogical model was specially remarkable.

In this sense, the authors' opinion is supported by the criteria offered by Bates (2001) that points out that the problem is not how to use a particular technology, but the lack of a conceptual framework and an appropriate methodology to guide the use of technology and of other elements of the teaching-learning process in general. In our opinion, it means that the persistent difficulties in implementing a methodological work system adversely affect the way and the basis upon which the current teaching practice of university teachers in Municipal Higher Education Institutions (MHEIs) of Physical Culture is being conducted.

It is considered that methodological work is an important and the most swift way to achieve a higher efficiency of teaching in general - and of the pedagogical expertise of each teacher in particular. Its essential functions are to ensure the achievement of the aimed educational and learning objectives, to grant the necessary planning and organization of the process, thus allowing the systematic structuring of all educational activities in order to dynamically respond to the changes 
provoked by the scientific-technical revolution and the growing needs of the country.

- Despite the acceptance of the teaching aids by teachers, there is a low presence of them in the TLP. The incorporated teaching aids are not always used according to their educational potential or the role they could potentially play. They are used in a non-integrated, fragmented way, which limits considerably their use.

- Many teachers recognize that, despite the lack of resources, they actually do not use available teaching aids regularly, arguing that their use is very complicated in blended learning class meetings $(66.3 \%)$.

This aspect allows us to reflect on what was said by Bravo (2004, p. 1):

Any media can become a teaching tool if it meets or helps to meet learning objectives. But its effectiveness will be greater when their use is planned within a strategy or model that meets the needs of the subjects the students have to learn. All teaching aids, to be effective, require planning and, ultimately, a model of implementation which will depend on the specific characteristics of the subject they serve.

With the purpose of confirming the data provided by the above mentioned documents and the information provided by the teachers' surveys and seeking to overcome the technical limitations that the data collection process may have, a direct and indirect observation of 28 classes -with the following distribution: six practical sessions, two workshops, eight conferences, four labs and four in-class sessions - was carried out. These observations allowed for more certainty in the collecting data process and to deeply research the use of teaching aids by teachers in the teaching-learning process, and consequently to make a critical analysis of how these aids are used in the process.

The main results are summarized in the following aspects:

- From a total of 24 classes observed, 19 were evaluated as fair $(79.1 \%)$ and 5 as good (20.8\%). The main difficulties identified were:

- $\quad$ Reduced use of teaching aids, specially of those belonging to the group of ICT and audiovisual tools.

- Almost complete absence of a systematic encompassing teaching aids with the other didactic components.

Following the approach of Labbé (2006, p. 2), whose view is shared by the authors of the present study:

To admit that teaching aids are constituent parts of the TLP means that they will interact with other instructional components (objectives, content, strategies, activities, etc.) modulating and conditioning their design and vice versa. (...) One of the main challenges of incorporating material aids in teaching is to harmonize their use, their role and their interaction with other factors that are considered vital in the teaching-learning context (objectives, content, strategies, etc..), in connection with the achievement of the aimed educational goals

The study carried out in the Municipal Higher Education Institutions (MHEIs) clearly revealed that the mastery in using teaching aids has not changed the teaching methodology or the way of structuring contents. This is an echo of the inadequate didactic preparation, a misconception of teaching that rules the use of teaching aids in blended learning.

The conclusions provided by several studies (Bates, 2001; Fernández \& Cebreiro 2002; Fuentes, 2003; Area, 2010; Monereo, 2010) contribute to a better understanding of this phenomenon. In general, these authors agree with the view that the technological material aids incorporate some changes in the dynamics of the teaching-learning process, but not in teaching practices that are still essentially based on a non-systematic, non- integrated approach of these didactic components in the process.

- A hundred percent of teachers showed mastery of content, but not of the teaching tools used. Gaps in self-preparation and planning were observed. Teaching aids were not included and, even less, specific tools related to the type of class taught. The used teaching aids did not appear in the teacher's lesson plan and they were not suitable for the inclass sessions in the frame of blended learning model. Since teachers neglect - in most of the cases - the technical aspects of the learning environment and the conditions of the classroom where those teaching aids are to be placed, which are mostly inadequate.

- Despite the fact that one of the main characteristics of the face-to-face sessions is that teacher offer guidance concerning the content and tasks with the use of teaching aids. In a large percentage of the classes sampled (75\%) it was not required the use of ICT, except for the Data Analysis subject, which requires the use of computers.

- However, the fact that the tasks designed by the teacher were limited by $62.5 \%$ basically to "download" digital materials from the server, or to visit the faculty website to assess the students' study for future classes, shows the difficulty of applying ICT-based teaching aids in the classroom.

It is worth revealing the essence of this contradiction, from the assessment carried out by Casas (2005), about the importance and need to change our educational practices. He points out that: "Once we are convinced of the urgent need for deep changes in most of the existing universities, the main obstacle is the attitude and the preparation of much of the faculty members (principals, teachers, researchers, managers and technicians)"

\subsection{Analysis of the results provided by the"Osgood Semantic Differential" scale, applied to teachers from the studied Municipal Higher Education Institutions (MHEIs).}

The ways in which attitudes are reflected in behavior and activity often depend on the situation. This analysis takes in consideration the results of the application of other research tools such as the survey and the observation, that allowed us to fully understand complex patterns of teachers' behavior towards the use of teaching aids. This way, we could evaluate how the current conditions, challenges and demands imposed by society and, in particular, by the Blending learning model used for professional training in Municipal Higher Education Institutions (MHEIs) affect and impact on the professional practice of the university teachers.

The attitude scale used was designed to measure the affective component (acceptance-rejection) of the surveyed teachers, to 
the following attitude object: Use of teaching aids in the teaching-learning process.

According to Murillo, the ways in which attitudes are reflected in the behavior and activity often depend on the specific situation in which they appear. This author defines attitude as:

(...) The state of psychological fitness, learned and organized through experience, that encourages the individual to react in a specific manner to certain stimuli, and involves prioritizing the affective component over the cognitive component (Murillo, 2003, p. 9).

In the table below, we present the scales concerning the three attitude objects in the surveys (Lombillo, 2008); the conducted statistical processing makes it possible to determine the grades of the group and, therefore, to establish partial conclusions related to this analysis.

The implementation of each of the previously explained steps allowed us to arrive at the following conclusions on the application of the scale:

The concept of ICT in the teaching-learning process is perceived by teachers in the studied institutions in the scale of bipolar adjectives: [important and insignificant] as quite important (1.70) and (0.75) [neither important nor insignificant] is the average grade for the mentioned concept (Table 2) in this scale, which corresponds to the results achieved in the first stage of the study and in the research project "Collaborative learning network", where attitudes toward the use of ICT as teaching aids were not encouraging. This allowed the authors of this research to state that "ICT tools are still a pending issue for teacherstutors and students" (Gallego, Martín-Cuadrado, \& Cacheiro, 2010, p. 175).

Table 2. Teachers' attitudes towards the concept $I C T$ in the teachinglearning process in the Municipal Higher Education Institutions (MHEIs)

\begin{tabular}{ccc}
\hline Couple/ bipolar adjectives & $\begin{array}{c}\text { Factorial } \\
\text { grade }\end{array}$ & Scale assessment \\
\hline Important and insignificant & +1.70 & Quite important \\
Positive-negative & +1.84 & Slightly positive \\
Progressive -traditional & +2.55 & Quite progressive \\
Flexible -restrictive & -1.42 & Somewhat restrictive \\
Necessary -unnecessary & 0.51 & Neither one nor another \\
Easy-difficult to use & -1.98 & Somewhat difficult \\
\hline Group's factorial grade for the concept & 0.75 (neither important nor \\
insignificant)
\end{tabular}

This attitude merely changed in the answers given to the concept: traditional teaching aids in the teaching-learning process, where the average total grade $(+1,39)$ indicates that the group considered it as somewhat important. In this respect, teachers do recognize the value of the traditional teaching aids, which are still indispensable in the teaching-learning process. See the following (Table 3 ) for a comparison of both concepts.
Table 3. Comparison of teachers' attitudes towards the concepts Traditional Teaching Aids (TTA) and ICT in the TLP of the Municipal Higher Education Institutions (MHEIs)

\begin{tabular}{cccc}
\hline $\begin{array}{l}\text { ICT in the TLP of Municipal Higher } \\
\text { Education Institutions (MHEIs). }\end{array}$ & $\begin{array}{c}\text { TTA in TLP OF Municipal } \\
\text { Higher Education } \\
\text { Institutions (MHEIs). }\end{array}$ \\
\hline Total & Assessment & Total & Valoración \\
\hline+1.70 & Quite important & +1.92 & Quite important \\
+1.84 & Slightly positive & +1.52 & Somewhat positive \\
+2.55 & Quite progressive & -1.35 & Somewhat traditional \\
\hline-1.42 & Somewhat restrictive & +1.19 & Somewhat flexible \\
0.51 & Neither necessary nor & +2.06 & Quite necessary \\
& unnecessary & & Neither easy nor \\
-1.98 & Somewhat difficult & 0.75 & $\begin{array}{c}\text { difficult } \\
0.75\end{array}$ \\
\hline
\end{tabular}

In considering the design of the combination of traditional and ICT-based teaching aids in the teaching-learning process, the average total grade $(+1,44)$ expressed in the assessment scale shows that the concept is perceived by teachers as being somewhat appropriate, which means that a large number of teachers agrees that this integration is quite necessary and pertinent (Table 4).

Table 4. Teachers' attitudes towards the concept: Integrated use of traditional teaching aids and ICT.

\begin{tabular}{cc}
\hline $\begin{array}{c}\text { Integrated use of Traditional Teaching Aids and ICT in the TLP } \\
\text { of Municipal Higher Education Institutions (MHEIs). }\end{array}$ \\
\hline Total & Assessment \\
\hline+1.83 & Quite appropriate \\
+1.49 & Somewhat positive \\
-1.38 & Somewhat traditional \\
\hline Group's factorial grade for the & +1.44 (Somewhat appropriate) \\
\hline concept & \\
\hline
\end{tabular}

Basing on the analysis of the research results concerning the first group of eight MHEIs, Lombillo (2008) expressed that:

the problem is not primarily in the used - traditional or technologically developed - aids, but mainly in the use made of them in the teaching-learning process, which will trace the guidelines for the development of good practices with teaching aids, especially if this happens with the best of all approaches: the integrated one.

From the study it is evident that there is an attitude of resistance by teachers to meet the current requirements to introduce and assimilate technological aids in their educational practice.

The above analyzed information can be better understood and interpreted from the following summary, including all regularities expressed in the results of the implemented instruments:

- Inadequate use of teaching aids, specially of those that are part of the computer and audiovisual technologies. 
- Lack of a systematic, progressive use of teaching aids integrated with other didactic components - in the teaching-learning process.

- Teachers declare an occasional use of teaching aids in the teaching-learning process, indicating that teaching aids are not integrated as a didactic component.

- The actual selection of teaching aids made by teachers shows the type of aids they often use in their classes: teaching aids for oral communication, manipulative aids and written teaching aids.

\section{CONCLUSIONS}

(1) The current practice of using teaching aids in the process of blended learning in the Municipal Higher Education Institutions (MHEIs) of Physical Culture in Havana province is characterized by a non-systematic, occasional use, with a particular tendency to an attitude of resistance to the use of ICT.

(2) As a result of inadequate skills and lack of use of ICTbased teaching aids in the TLP, the technological literacy of teachers is still limited. Mistakes are made when using traditional and ICT-based teaching aids without applying a correct didactic-methodological strategy that facilitates their coherently integrated and progressive use.

(3) The results obtained from the attitude scale show that teachers have a positive attitude to the use of traditional teaching aids in comparison with the use of ICT, which allow us to explain the fact that the current education practice including traditional and ICT-based teaching aids in the Municipal Higher Education Institutions (MHEIs) of Physical Culture of Havana province is essentially based on a non-systematic, nonintegrated approach.

\section{REFERENCES}

Álvarez, I. B. \& Fuentes, H. (2005). Didáctica del proceso de formación de los profesionales asistido por las tecnologías de la información y la comunicación. Revista Pedagogía Universitaria, 10 (3). Retrieved from http://cvi.mes.edu.cu/peduniv/base-de-datos/2005-vol.-x-no.3/presentacion-introduccion-y-capitulo-i-las-tecnologias-de-lainformacion-y-la-comunicacion-breve-caracterizacion

Area, M. (1991). La investigación sobre medios de enseñanza: pasado y presente. In M. Area, Los medios, los profesores y el currículo (pp. 1-17). Barcelona: Sendai Ediciones.

Area, M. (1999). Los materiales curriculares en los procesos de diseminación y desarrollo del currículum. In J.M. Escudero (Ed.), Diseño, desarrollo e innovación del currículum (pp. 189-208). Madrid: Síntesis.

Area, M. (2010). El proceso de integración y uso pedagógico de las TIC en los centros educativos. Un estudio de casos. Revista de Educación, (352). $\quad$ Retrieved r from http://www.revistaeducacion.mec.es/re352/re352_04.pdf

Bates, T. (2001). Cómo gestionar el cambio tecnológico. Estrategias para los responsables de los centros universitarios. Barcelona: Gedisa.

Bravo, J. L. (2004). Los medios de enseñanza: clasificación, selección y aplicación. Pixel-Bit, Revista de Medios y Educación (24). Retrieved from http://www.sav.us.es/pixelbit/pixelbit/articulos/n24/n24art/art2409.ht $\mathrm{m}$

Cabero, J., Llorente, M. C. y Marín, V. (2010). Elearning como objeto de investigación: meta-análisis y usos en la enseñanza superior. En R. Roig Vila, \& M. Fiorucci (Eds.), Claves para la investigación en innovación y calidad educativa. La integración de las Tecnologías de la Información y la Comunicación y la Interculturalidad en las aulas. Strumenti di rucerca per l'innovazione e la qualità in ambito educativo. Le Tecnologie dell'informazione e della Comunicazione e l'interculturalità nella scuola (pp. 85-98). Alcoy: Marfil.

Casas, M. (2005). Nueva universidad ante la sociedad del conocimiento. Revista de Universidad y Sociedad del Conocimiento, 2(2). Retrieved from http://www.uoc.edu/rusc/2/2/dt/esp/casas.pdf

Castañeda, A. E., Ruiz, L., \& López, A. (2010). Rumies a una década de innovaciones para la asimilación de las TIC en la enseñanza universitaria de carreras no pedagógicas. En Las TIC en el aprendizaje de las Ciencias Técnicas. XV Convención Científica de Ingeniería y Arquitectura TICACT - CCIA 15. La Habana, Cuba.

Castañeda, Á. E. \& Fernández de Alaiza, V. (2002). Aplicaciones de las Nuevas Tecnologías de la Informática y las Comunicaciones en el proceso de enseñanza-aprendizaje. Lima: Universidad Técnica de Ambato.

Castaño, C. (1994). Las actitudes de los profesores hacia los medios de enseñanza. Pixel-Bit, Revista de Medios y Educación (1). Retrieved from

http://www.sav.us.es/pixelbit/pixelbit/articulos/n1/n1art/art15.htm

Cubero, J., González, V., Tristá, B., \& Hernández, G. (1985). Los medios de enseñanza en la Educación Superior. Ciudad de La Habana: Universidad de La Habana.

Fernández, M. C \& Cebreiro, B. (2002). La integración de los medios y nuevas tecnologías en los centros y prácticas docentes. Pixel-Bit, Revista de Medios y Educación (20). Retrieved from http://www.sav.us.es/pixelbit/pixelbit/articulos/n20/n20art/art2003.ht $\mathrm{m}$

Fernández, A. M. (2009). La comunicación. Su importancia en la educación. Estilos de comunicación. In O. Ginoris, Fundamentos didácticos de la Educación Superior Cubana. Selección de lecturas (pp. 421-433). La Habana: Félix Varela.

Fuentes, J. A. (2003). Dificultades en la integración curricular de los medios y las tecnologías de la información y de la comunicación: estudios de casos en la provincia de Granada (Tesis doctoral). Retrieved from http://dialnet.unirioja.es/servlet/tesis?codigo $=13660$

Gallego, D. J., Martín-Cuadrado, A. M. \& Cacheiro, M. L. (2010). Aprendiendo de forma colaborativa a través de las herramientas Web 2.0. En R. Roig Vila, \& M. Fiorucci (Eds.), Claves para la investigación en innovación y calidad educativa. La integración de las Tecnologías de la Información y la Comunicación y la Interculturalidad en las aulas. Strumenti di rucerca per l'innovazione e la qualità in ambito educativo. Le Tecnologie dell'informazione e della Comunicazione e l'interculturalità nella scuola (pp. 163-178). Alcoy: Marfil.

García-Valcárcel, A. \& González, A. D. (2011). Integración de las TIC en la práctica escolar y selección de recursos en dos áreas clave: lengua y matemática. In R. Roig, \& C. Laneve (Eds.), La práctica educativa en la Sociedad de la Información. Innovación a través de la investigación. La pratica educativa nella Società dell'Informazione. L'innovazione attraverso la ricerca (pp. 129-144). Alcoy: Marfil.

García-Valcárcel, A. y Tejedor F. J. (2010). Características y valoración de los escenarios de enseñanza-aprendizaje con TIC en el ámbito universitario. En R. Roig Vila, \& M. Fiorucci (Eds.), Claves para la investigación en innovación y calidad educativa. La integración de las Tecnologías de la Información y la Comunicación y la Interculturalidad en las aulas. Strumenti di rucerca per l'innovazione e la qualità in ambito educativo. Le Tecnologie dell'informazione e della Comunicazione e l'interculturalità nella scuola (pp. 179-192). Alcoy: Marfil.

González, P. O. (1995). Didáctica universitaria. Centro de Estudios para el Perfeccionamiento de la Educación Superior (CEPES). La Habana:Universidad de la Habana.

Guzmán, M. D. \& Aguaded, J. I. (2011). Planes de integración de TIC en contextos educativos. In R. Roig, \& C. Laneve (Eds.), La práctica educativa en la Sociedad de la Información. Innovación a través de la investigación. La pratica educativa nella Società dell'Informazione. L'innovazione attraverso la ricerca (pp. 201212). Alcoy: Marfil.

Horruitiner, P. (2006). La Universidad Cubana: El modelo de formación. La Habana: Félix Varela.

Labbé, C. G. (2006). Uso pedagógico de los medios. [CDROM].España.

Lombillo, I. (2006). La utilización de los medios de enseñanza y las Tecnologías de la Información y las Comunicaciones en la nueva Universidad Universalizada. ¿Una relación dinámica?. Revista Pedagogía Universitaria, 11(3). Retrieved from 
http://cvi.mes.edu.cu/peduniv/base-de-datos/2006-vol.-xi-no.-3/lautilizacion-de-los-medios-de-ensenanza-y-las-tecnologias-de-lainformacion-y-la-comunicacion-en-la-nueva-universidaduniversalizada.-una-relacion-dinamica

Lombillo, I. (2008). Propuesta de estrategia metodológica para potenciar el uso de los medios de enseñanza tradicionales y las TIC en las SUM de Cultura Física de La Habana (Tesis doctoral). Ciudad de la Habana, Cuba.

Lombillo, I. (2011). Estrategia metodológica para el uso integrado y progresivo de los medios de enseñanza por docentes de la Universidad Agraria de La Habana (Tesis doctoral). La Habana. Ciudad de la Habana ,Cuba.

López, A. (2005). Contribución al desarrollo de la habilidad "Diagnóstico Patológico" en la Carrera de Medicina Veterinaria. Tesis Doctoral. Instituto Superior Politécnico José Antonio Echeverría, Centro de Referencia para la Educación de Avanzada (CREA-CUJAE). Cuba.

López, A. (2007). Metodología para la asimilación de las Tecnologías de la Información y las Comunicaciones en el proceso de enseñanza aprendizaje de las Ciencias Técnicas Agropecuarias. Revista Ciencias Técnicas Agropecuarias, 2(16), 63-68.

López, A. (2009, Octubre). Las TICs y su relación con la formación del veterinario en el contexto de la Educación Superior Cubana del siglo $X X I$. Conferencia en Congreso Internacional Latinoamericano de Avicultura 2009. Palacio de las Convenciones de La Habana, Cuba.

Marquès, P. (2004). Evaluación e investigación educativa: competencias básicas en las tecnologías de la información y la comunicación (TIC). Consejería de educación cultura y deportes del gobierno de Canarias. Instituto Canario de Evaluación y Calidad Educativa (ICEC). Canarias.

Ministerio de Educación Superior (2004). Universalización de la Universidad. Informe a la Asamblea Nacional del Poder Popular. La Habana, Cuba.

Monereo, C. (2010). ¡Saquen el libro de texto! Resistencia, obstáculos y alternativas en la formación de los docentes para el cambio educativo. Revista de Educación, (352), 583-599.

Murillo, F. J. (2003). Cuestionarios y escalas de actitudes [CD-ROM] Facultad de Formación de profesorado y Educación. Universidad Autónoma de Madrid.

Nápoles, N. (2011). Estrategia de alfabetización informacional para la producción de objetos de aprendizaje en la carrera de Ingeniería Agronómica en la Universidad Agraria de La Habana. Tesis de doctorado en Ciencias de la Educación. Mayabeque, Cuba.

Pere, J., Devís, J., y Peiró, C. (2008). Materiales curriculares: clasificación y uso en Educación Física. Revista de Medios y Educación Pi xel-Bit (33). Recuperado de $\begin{array}{lll}\text { xel-Bit } & \text { (33). } & \text { Recuperado } \\ \text { http://www.sav.us.es/pixelbit/pixelbit/articulos/n33/n33.html }\end{array}$

Rico, P., López, J., Chávez, J., Ruiz, A. y Valera, O. (2002). Proyecto de Pedagogía del ICCP. Marco conceptual para la elaboración de una Teoría Pedagógica. Instituto Central de Ciencias Pedagógicas: Ciudad de La Habana.

Roig, R. (2010). Innovación educativa e integración de las TIC. Un tándem necesario en la sociedad de la información. En R. Roig Vila y M. Fiorucci (Eds). Claves para la investigación en innovación y calidad educativa. La integración de las Tecnologías de la Información y la Comunicación y la Interculturalidad en las aulas. Strumenti di rucerca per l'innovazione e la qualità in ambito educativo. Le Tecnologie dell'informazione e della Comunicazione e l'interculturalità nella scuola (pp. 329-340). Alcoy: Marfil.

Ruiz, A. (1999). La triangulación. En (n.a.), Metodología de la investigación Educativa. Brasil: Ed. Grifo Chapecó.

Salinas, J. (2002). Las TIC como medios para una nueva universidad. Efectos de la introducción de las TIC en la mejora de la docencia universitaria. $2^{\circ}$ Congreso Internacional Docencia Universitaria $e$ Innovación [CD-ROM]. Tarragona, España.

Torres, A. (2008). Una concepción teórico-metodológica para la producción de teleclases en formato digital destinadas a la Nueva Universidad cubana (Tesis de Doctorado). Universidad Agraria de La Habana, Cuba.

Valera Alfonso, O. (2008). La universalización de la educación superior en la provincia La Habana. Una mirada integral desde los resultados cientificos de un proyecto I.D.I. .VI Congreso Internacional de Educación Superior. Universidad 2008. II Taller Universalización de la Universidad. Ciudad de La Habana, Cuba. 